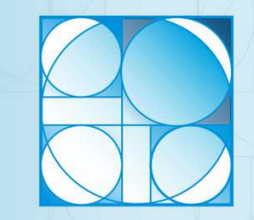

Revista de Ensino de Bioquímica

Revista de Enseñanza de Bioquímica

$2^{\circ}$ Prêmio Nacional de Ensino de Bioquímica e Biologia Molecular

C4 Sociedage Brasileira de Bioguimica

ISSN: 2318-8790

ISSN (until 2012): 1677-2318

Sociedade Brasileira de Bioquímica

e Biologia Molecular - SBBq

$48^{\circ}$. Reunião Anual da SBBq

14 a 17 de maio de 2019 - Águas de Lindóia, SP

\title{
Symposium 19
}

Promoting the divulgation of teaching and research in Biochemistry and Molecular Biologyl

Chair: profa. Dra. Vera Treis Trindade

\section{Dissemination of digital educational content: experiences with the Digital Library of Sciences (BDC), YouTube and App stores}

\begin{abstract}
Eduardo Galembeck
Departamento de Bioquímica e Biologia Tecidual, Instituto de Biologia, Universidade Estadual de Campinas, UNICAMP, Campinas, SP, Brazil.
\end{abstract}

The publication of online digital content is a practice that is growing in importance in the academic world. The dissemination of academic production in an accessible way, in media that go beyond the specialized journals, is a powerful way of approximating the universities with the general public. Committed in the production of digital content aimed at Teaching Biochemistry since the end of the 90s, I had the opportunity to try different ways of disseminating these contents. In this presentation will be traced a timeline of the development of the technologies we use in the publication of digital content dissemination, starting from the first diskette given with software to three or four people interested in software presented in the SBBq's poster sessions during the 90s, to the distribution of online content at BDC, App stores and Youtube that reach over 1 million downloads and spread such content across the globe. The new technologies of information and communication have not only been effective to spread knowledge, but it has now allowing to understand how it has been used by the following their trace.

Keywords: Education, Outreach, Internationalization 